\title{
The Effect of Sharia Governance and Customer Relationship Marketing on Muzakki Loyalty
}

\author{
Mahmudi $^{1, \mathrm{a} *}$, Rizka Luluh Prastmawati ${ }^{1, \mathrm{~b}}$ \\ ${ }^{1}$ Department of Accounting, Faculty of Business and Economics Universitas Islam Indonesia \\ Ring Road Utara, Condongcatur, Sleman, Yogyakarta, Indonesia \\ e-mail: ${ }^{a *}$ mahmudi@uii.ac.id, ${ }^{\mathrm{b}}$ rizkaluluh94@gmail.com \\ * Corresponding Author
}

\begin{abstract}
This study aims to analyze the effect of sharia governance and customer relationship marketing on muzakki loyalty. In this study, sharia governance was divided into six variables, i.e. transparency, accountability, responsibility, independence, fairness, and sharia compliance. Whereas customer relationship marketing was divided into four variables, i.e. trust, communication, commitment, and customer intimacy. We employed survey as a preferred method to obtained data. The samples of this study consisted of 200 muzakki (zakat payer) at amil zakat institutions (LAZ) in Yogyakarta, Indonesia. The data was analyzed using OLS regression techniques. The results of this research found that transparency, fairness and sharia compliance have a positive significant effect on customer loyalty, while accountability, responsiveness, and independency do not have significant effect on customer loyalty. Regarding the variable of customer relationship marketing, the result showed that communication, trust, and customer intimacy have a positive and significant effect on muzakki loyalty while commitment has no effect. It can be inferred that sharia governance and customer relationship marketing partially have a positive effect on muzakki loyalty.
\end{abstract}

Keywords: Customer Relationship Marketing, Muzakki Loyalty, Sharia Governance

Article History: Received: August, 192020 Revised: September, 152020 Accepted: October, 92020

How to cite: Mahmudi., \& Prastmawati, R. L. (2020). The Effect of Sharia Governance and Customer Relationship Marketing on Muzakki Loyalty. Akrual: Jurnal Akuntansi, 12(1):1-17.

DOI: https://doi.org/10.26740/jaj.v12n1.p1-17

\section{INTRODUCTION}

There are several studies that analyzed the potential of zakat in Indonesia (see for example: Firdaus et al., 2012; Mubarok and Fanani, 2014; Rijal and Nilawati, 2019). Based on these studies, the potential of zakat in Indonesia has an increasing annual trend. Unfortunately, the potential of zakat in Indonesia as revealed by these studies has not been supported by the realization of zakat funds collected. Recent data show that there is a quite large gap between the potential of zakat and the actual collection of zakat funds. In 2018, although the potential of zakat funds in Indonesia reached more than IDR 200 trillion, but only IDR 5.2 trillion was collected (Rahman, 2018).

The large gap between the potential of zakat and the amount of zakat collected leads to many questions. Whether the lack of sharia governance and customer relationship 
management (CRM) were the significant factors causing the low zakat collection. This research aims to investigate the role of sharia governance and CRM in affecting muzakki (zakat payer) loyalty. This research is relevant to the current issues which demand the need for improvement in sharia governance of institutions that adopt Islamic values. Various studies in Islamic corporate governance have been conducted in Islamic banking context (Indrawaty and Wardayati, 2016). However, the study of sharia governance in the nonbanking industry such as amil zakat institutions is very limited. This research is intended to fill this area.

As a religious institution that manages public funds, zakat management organizations (Organisasi Pengelola Zakat - OPZs) are obliged to report the zakat collection and distribution performance to its stakeholders. The reports of zakat fund management include planning, implementation, administration, finance, accountability and financial supervision of zakat management. If the accountability report has met the predetermined rules, it will influence public trust to pay zakat through the relevant zakat institutions. In addition, the report must also adhere sharia governance.

Optimizing the collection of zakat related to increasing the number of muzakki. The increasing number of muzakki will directly affects the amount of zakat collected. As a public institution, OPZ is expected to initiate strategies to maintain muzakki loyalty, instead of increasing the amount of zakat collected only. OPZ should develop customer relationship marketing program to maintain muzakki loyalty. Customer relationship marketing is the process of creating, maintaining and improving strong relationship which provides high value for customers and other relevant parties. In Indonesia, OPZ is divided into two types, namely Amil Zakat Institution (Lembaga Amil Zakat - LAZ) and National Zakat Agency (Badan Amil Zakat Nasional - BAZNAS). This study focuses on LAZ because LAZ does not belong to the government, so it must try to obtain zakat revenue from the Muslim community more aggressive and independent. Meanwhile, BAZNAS as a zakat institution under the government control has a captive source of zakat income, namely from cuts in civil servants' salaries.

This study provides several theoretical and practical contributions. This study provides new empirical evidence regarding the role of sharia governance and customer relationship marketing in the context of zakat management organizations in increasing muzakki loyalty. This research can also be used as a consideration for amil zakat in developing zakat empowerment programs, especially to enhance zakat payer loyalty.

Loyalty is an attitude or behavior of a customer that leads benefits for a company, including repurchasing the products or services of a company and recommending those products and services to others (Wantara, 2015). According to Tjiptono (2012) loyalty is a commitment made by customers to the company, brand or product based on a positive attitude, manifested in the form of consistent repeat purchases. In zakat paying context, muzakki loyalty means a commitment made by the muzakki to zakat management 
organization (Organisasi Pengelola Zakat - OPZ) because they are satisfied with the process, which is manifested in repeat zakat paying through the same OPZ.

There are many factors affecting loyalty. This study highlights two factors that probably affect muzakki loyalty, i.e. sharia governance and customer relationship marketing. Sharia governance in this study is the development of the concepts of corporate governance and sharia compliance. Corporate governance principles are universal principles, while sharia compliance is the operational principles of Islamic financial institutions. Whereas customer relationship marketing is one of business approaches by managing the interaction or relationship between a company and its customers. Customer relationship marketing is the process of creating, maintaining and improving strong relationships which provide high value to customers and other relevant parties (Kotler \& Armstrong 2012). Relationships in customer relationship marketing are partnership, instead of mere relationship between sellers and buyers. Thus, customer relationship marketing has long-term goals.

\section{Sharia Governance}

\section{Transparency and Muzakki Loyalty}

Muzakki needs transparency in terms of information about the distribution and collection of zakat. Thus, zakat management institutions are obliged to disclose information in a timely, adequate, clear, accurate, and comparable manner, and make it easily accessed by muzakki according to their rights. Muzakki will feel satisfied when they could access information easily and completely.

Based on the theory of marketing proposed by Kotler, an individual or group pursue to obtain what they need or want by creating and exchanging products or services with each other. According to this theory, transparency and disclosure of information are important to explain to the customers about the products or services that a company has and to find out what customers want in the future.

The studies conducted by Yuliafitri \& Khoiriyah (2016) and Inayah \& Muanisah (2016) showed that transparency has a significant effect on customer loyalty. However, contradictive results revealed from the studies conducted by Purnamasari \& Darma (2015) and Ramadan et al., (2018). They found that transparency did not have any effect on loyalty. This study predicts that transparency provided by OPZ will enhance muzakki loyalty. Based on the above explanation, hypothesis 1 is stated as follows:

\section{$H_{1}$ : Transparency has a positive effect on muzakki loyalty}

\section{Accountability and Muzakki Loyalty}

Accountability is a principle where the managers are obliged to promote an effective accounting system to produce reliable financial statement (Fadilah, 2012). Marketing and accountability theories are closely related because marketing theory also emphasizes 
clarity in marketing, including who, why, how and whether the marketing of a company is accountable.

Zakat management organization are also obliged to demonstrate clear accountability in performing their responsibility for the authority predetermined since this may affect the level of muzakki trust in those institutions, thus influencing the level of loyalty. This statement is supported by a research conducted by Rozi et al., (2014), revealing that accountability has a significant effect on customer loyalty. However, different results from Islamic banks were shown by studies of Purnamasari \& Darma (2015) and Inayah \& Muanisah (2016), showing that accountability does not have any effect on customer loyalty. This study predicts that accountability will improve muzakki loyalty. Based on the above explanation, hypothesis 2 is formulated as follows:

\section{$\mathrm{H}_{2}$ : Accountability has a positive effect on muzakki loyalty}

Responsibility and Muzakki Loyalty

Maintaining business continuity must adhere to the responsibility principle and ensure the implementation of applicable regulations. In addition, an organization must also act as an agent of several aspects, e.g. economic agent, social change, as well as environmental agent. Trust will increase if a company obeys predetermined regulations, conducting business ethically, and cares for the environment and society, thus influencing customer loyalty to the company. This is the reason why zakat management organizations also have to implement these principles.

Purnamasari \& Darma (2015) stated that good corporate governance has a significant effect on customer loyalty. One of the principles of good corporate governance discussed in their study is responsibility. The study conducted by Ramadan et al., (2018) showed that responsibility has a significant positive effect on loyalty. This study predicts that if the zakat management organization has a high responsibility, it will increase the loyalty of muzakki. Hypothesis 3 was formulated as follows:

\section{$\mathrm{H}_{3}$ : Responsibility has a positive effect on muzakki loyalty}

\section{Independence and Muzakki Loyalty}

Independence is a situation where the management of an organization is carried out professional work free from any conflict of interest and influence from management that is not in line with the applicable laws and regulations, and sound corporate principles. In addition, the independence of an organization is also required to adhere to the applicable laws and regulations (Purnamasari \& Darma 2015).

This principle is also applicable to public institutions engaged in religious activities such as zakat management organizations. OPZs are also obliged to manage their organizations professionally, be free from pressure from other parties and should comply with the applicable regulations because these can be an added value for OPZs from the perspective of muzakki. Ramadan et al., (2018) found that independence has a positive 
effect on loyalty. However, the study conducted by Purnamasari \& Darma (2015) provide different result that independence has no effect on loyalty. Thus, hypothesis 4 can be formulated as follows:

\section{$H_{4}:$ Independence has a positive effect on muzakki loyalty}

Fairness and Muzakki Loyalty

OPZs as public institutions that are directly related to the community are also obliged to be as fair as possible in interacting with muzakki to fulfill their needs because muzakki is the spearhead of OPZs in the future. In marketing activities, customers are satisfied when what they experience and perceive are as expected, or even exceed their expectations. This way, if OPZs are able to maintain specific criteria of each of the services provided to muzakki and provide fair and equal treatment to them as an effort to fulfill their rights, then muzakki will be loyal. This is supported by a research conducted by Purnamasari \& Darma (2015) and Ramadan et al., (2018), revealing that fairness has a significant positive effect on customers. Hypothesis 5 was formulated as follows:

\section{$H_{5}$ : Fairness has a positive effect on muzakki loyalty}

\section{Sharia Compliance and Muzakki Loyalty}

Sharia compliance is the compliance of Islamic institutions toward Islamic principles and regulations. OPZ as a religious public service institution that is directly involved in the collection and distribution of zakat paid by muzakki, ought to adhere to Islamic principles. Muzakki wishes the Amil Zakat to conduct transactions in good manners and does not violating Islamic principles. This is in line with a research conducted by Ramadan et al., (2018) and Purnamasari \& Darma (2015), showing that sharia compliance has a positive effect on loyalty. Hypothesis 6 was formulated as follows:

\section{$H_{6}:$ Sharia compliance has a positive effect on customer loyalty}

\section{Customer Relationship Marketing}

\section{Trust and Muzakki Loyalty}

Trust is the cornerstone that all Muslims must have, especially in relation to any party that deals with Muslim interests. In business, building a trust-based relationship between customers and the company is essential. Muzakki trust is very crucial for Amil Zakat Institutions because muzakki trust will determine the decision to pay zakat that will be collected and distributed by the Amil. Previous studies conducted by Haryeni et al., (2018), Razak et al., (2018), Inayah \& Muanisah (2018), Husnain \& Akhtar (2015), Ramadan et al., (2018) and Tabrani et al. (2018) found that trust has a positive effect on loyalty. Therefore, hypothesis 7 was formulated as follows:

\section{$H_{7}$ : Trust has a positive effect on muzakki loyalty}


Communication and Muzakki Loyalty

Communication in the context of customer relationship marketing is defined as an action to maintain relationship with customers, provide precise and accurate information, and actively communicate whenever there are problems (Ndubisi, 2015). If associated with marketing theory, communication is highly important because in the absence of communication between seller and buyer, marketing will not take place.

Similarly, open communication between OPZs and muzakki is very important because it can support their daily works, including in calculating, collecting, marketing (introducing zakat institutions to wider community), and distributing zakat to mustahiq (those entitled to receive zakat) so as to prevent distribution to wrong target group. Thus, communication is very important for the survival of an OPZ. Husnain \& Akhtar (2015) found that communication has a significant positive effect on loyalty. Hypothesis 8 was formulated as follows:

\section{$H_{8}$ : Communication has a positive effect on muzakki loyalty}

\section{Commitment and Muzakki Loyalty}

Commitment can be defined as a long-lasting willingness to maintain the value of relationships (Tabrani et al., 2018). Marketing is the process of introducing products to potential customers through various means so that customers are interested in using the products and services offered. If a company is able to create and take opportunities regarding what customers need by offering high quality with reasonable prices, then exchange of goods or services can take place. Nonetheless, a company must have a commitment to the services or products that they produce in order to survive in the market (Kotler and Armstrong, 2018).

This concept also can be applied for Amil Zakat Institutions. Commitment is crucial in order to keep their promises to muzakki who have entrusted Amil Zakat Institutions to collect their zakat funds so as to result in muzakki loyalty. This is supported by a research conducted by Husnain \& Akhtar (2015), and Tabrani et al. (2018) which found that commitment has a positive effect on loyalty. Hypothesis 9 was formulated as follows:

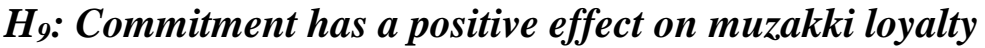

Customer Intimacy and Muzakki Loyalty

According to Anggriawan et al., (2015), customer intimacy is one of the popular strategies used by many companies in building and maintaining customer loyalty. Intimacy could help companies build relationships with customers and prevent the termination of relationships between the two parties. Marketing theory contains an integration of marketing activities, meaning that every person and every part of a company is involved in any of coordinated efforts to provide customer satisfaction so as to achieve a company's goals. Customer intimacy is an element of customer relationship marketing which is used as a corporate strategy to get a closer relationship to its customers. 
Amil Zakat Institutions can initiate approaching their muzakki by providing information about the procedures of zakat payment, zakat calculation, and always keeping in touch with muzakki. By maintaining good communication, it is expected that muzakki will feel respected and honored. This statement is in line with a research conducted by Tabrani et al. (2018) and Anggriawan et al., (2015), showing that customer intimacy has a positive effect on customer loyalty. However, it is in contrast to the research conducted by Rozi et al., (2014) that find customer intimacy does not have any effect on customer loyalty. Hypothesis 10 was formulated as follows:

\section{$H_{10}$ : Customer Intimacy has a positive effect on muzakki loyalty}

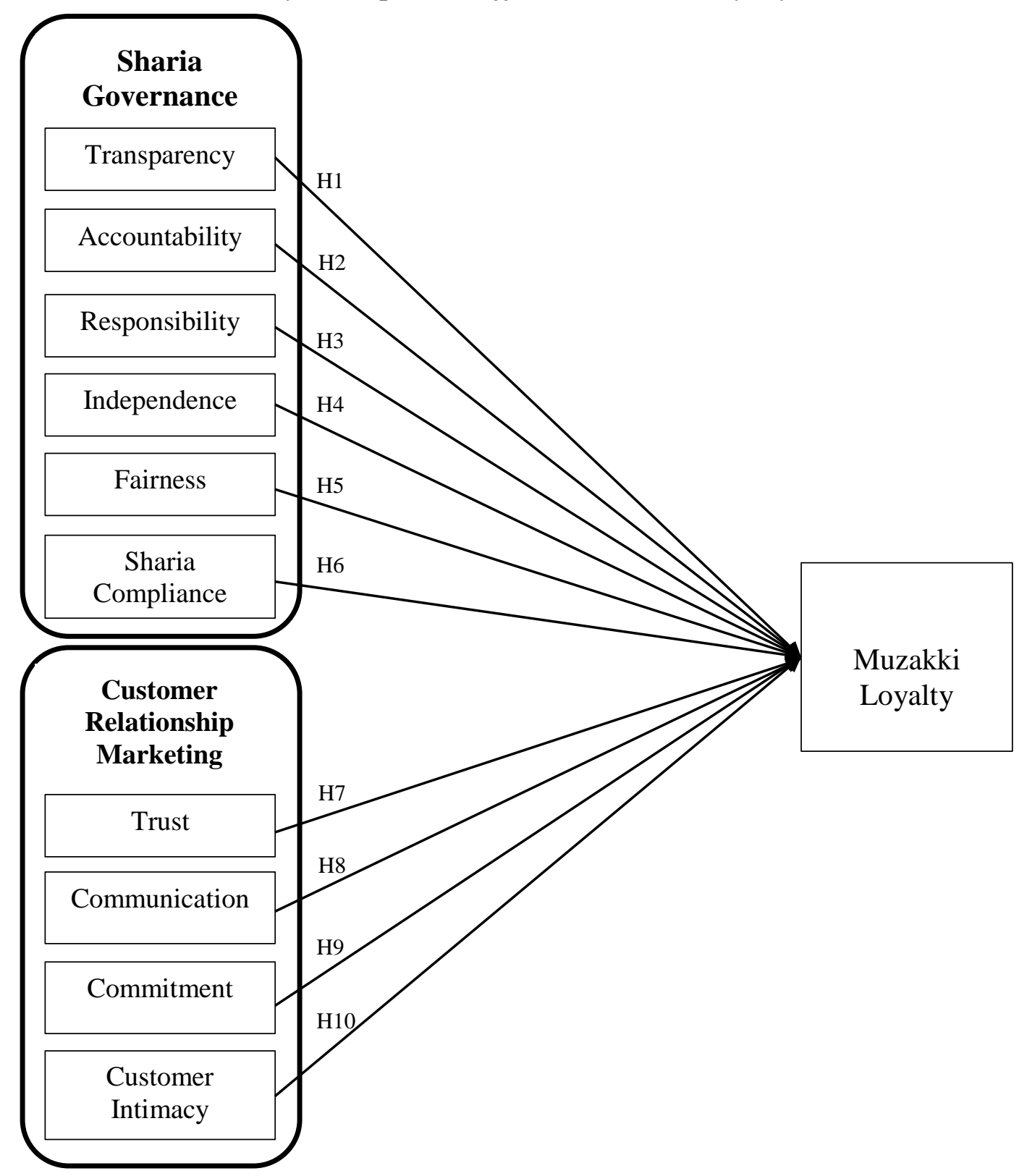

Figure 1. Research Framework 


\section{RESEARCH METHOD}

This study used a survey approach as a preferred method to collect data. The data was collected through distributing questionnaire to the respondents. The sample of this study are zakat payers who paid their zakat through Amil Zakat Institution (Lembaga Amil Zakat-LAZ) in Yogyakarta, Indonesia. The samples in this study were selected using convenience sampling. There were 200 respondents involved in this study. We distribute 215 questionnaires to the respondents. Of the 215 questionnaires distributed, there were 15 questionnaires that could not be processed because they were incomplete so that only 200 were included for further analysis. Thus, the response rate for this study was $93 \%$.

\section{Definition of Operational Variable and Measurement}

\section{Dependent Variable $(Y)$}

Muzakki Loyalty

In this study, the dependent variable was the loyalty of muzzaki (those who pay zakat) in Amil Zakat Institutions. The indicators which were used in this study included the relationship between Amil Zakat Institutions and Muzakki, zakat payment activities, how muzakki make recommendations to others, and the absence of muzakki's interest in paying zakat elsewhere (Yuliafitri \& Khoiriyah, 2016). Muzakki loyalty is measured by using questionnaire adapted from Yuliafitri and Khoiriyah (2016).

\section{Independent Variables $(X)$}

Transparency

According to KNKG (2006), transparency is a condition of an institution that can provide material and relevant information in a way that is easily accessible and understood by stakeholders. With transparency, it is expected to encourage information disclosure and the actual situation, so that stakeholders can measure and anticipate everything related to bank activities (Purnamasari \& Darma, 2015). The indicators used to measure transparency were the provision of information, ease of information, and provision of information about policies with a 5-point Likert scale (Yuliafitri \& Khoiriyah, 2016).

Accountability

According to the NCG (National Committee on Governance), the principle of accountability is a principle that managers are obliged to foster an effective accounting system in order to produce reliable financial reports (Fadilah, 2012). In the Islamic teachings, accountability has a view as the responsibility of a human being as caliph on earth to Allah SWT, because whatever has been entrusted to humans is mandate and every human being must be responsible for what he has done or done. This is explained in AlQuran surah Al-Mudassir: 38. The indicators used to measure the aspect of accountability included the details of functions, duties and responsibilities, the implementation of their duties, and performance measurement with a 5-point Likert scale (Yuliafitri \& Khoiriyah, 2016). 


\section{Responsibility}

Responsibility is the implementation of an action and decision according to the provisions, expertise, and ability in a mandate manner (Azheri, 2012). The indicators used to measure responsibility were to adhere to regulations and care for the environment and society with a 5-point Likert scale that was adopted from Purnamasari \& Darma (2015).

Independence

Independence means that the company carries out its functions properly and each participant must be free from the interests of other parties that have the potential to cause conflicts of interest, and carry out their functions in accordance with adequate competence (Warsono, et al, 2009). The indicators used to measure independence were professional management and responsibility, as well as independence without any interference from anyone with a 5-point Likert scale adapted from Junusi (2016).

\section{Fairness}

According to Purnamasari \& Darma (2015) justice is a fairness and equality in fulfilling the rights of stakeholders arising on the basis of applicable agreements and laws. Fairness refers to equal treatment to stakeholders in accordance with the criteria and proportions that should be (Purnamasari \& Darma, 2015). Justice is treating someone or other parties according to their rights. The matters of each individual are recognized and treated according to their dignity and status, equality, equality of rights and obligations, regardless of ethnicity, ancestry, and religion. The indicators used to measure fairness were justice and equality with a 5-point Likert scale adapted from Junusi (2016).

\section{Sharia Compliance}

Sharia compliance is an adherence to sharia principles, which means the organizations in their operations should comply with Islamic sharia provisions, especially concerning Islamic procedures (Junusi, 2016). The indicators used to measure sharia compliance were free from usury and gharar, halal business, and trustworthy business management with a 5-point Likert scale (Junusi, 2016).

Trust

Trust is defined as a belief in a promise from a partner that must be reliable and the party must be able to fulfill its promises in an ongoing relationship (Ndubisi, 2015). The indicators used to measure trust were security, promise, consistency in providing services, employees' attitude, fulfillment of obligation to society and partners' trust in the company with a 5-point Likert scale (Ndubisi, 2015).

\section{Commitment}

Ndubisi (2015) defines commitment as a desire to maintain a valuable relationship. Meanwhile, according to Tjiptono (2008) loyalty is a customer's commitment to a store, brand or product based on a positive attitude that is reflected in the form of repeated purchases consistently. Commitment can be described as long-term customer orientation towards business relationships that are based on emotional attachment. The indicators used to measure the aspect of commitment were the company or institution's adjustment 
to partners, service offerings, and service flexibility with a 5-point Likert scale (Ndubisi, 2015).

\section{Communication}

Communication is an expression of information and understanding, regarding verbal or nonverbal symbols. Communication is the process of transferring understanding in the form of ideas or information from one person to another (Ardiansyah, 2016). A company usually conducts marketing communication that suits with the character of its target customers. The indicators used to measure the aspect of communication were provision of precise and accurate information as well as making and keeping promises with a 5-point Likert scale (Ndubisi, 2015).

Customer Intimacy

Tabrani et al. (2018) defines customer intimacy as customer perception that has a very close and mutually beneficial understanding relationship between buyers and suppliers while according to Anggriawan et al. (2015) customer intimacy is a company's strategy to establish relationships with customers and how to build customer trust so that the company becomes a friend of the customer. Intimacy was built to create a framework between a company and customer, so as to create a strong bond between the two parties. The indicators used to measure customer intimacy were closeness, perceived value and mutual understanding (Tabrani et al., 2018).

\section{RESULTS AND DISCUSSION}

This research employed regression tests to analyze the data and hypothesis testing. Multiple linear regression tests were performed in order to test whether the hypothesis was accepted or not. The hypothesis was accepted if the significance value < probability value, i.e. 0.05 .

\section{Research Instrument Tests}

To ensure that the research instrument is suitable for use, the research instrument was tested for validity and reliability. The results of the instrument validity test in this study showed that each question has $r$ count $>r$ table $(0.3610)$ which was positive. This means that each of the questions was valid. Thus, all the questions met the requirements or could be used for this research and able to represent the variables under study.

The reliability test was performed using Cronbach's alpha and comparing the coefficient alpha with coefficient R i.e. 0.6 (Purnamasari \& Darma, 2015). Based on the test results, it can be seen that all the variables had Cronbach's alpha $>0.6$, thus each of the variables in this study was reliable. 


\section{Table 1. Results of Reliability Test}

\begin{tabular}{lc}
\hline Variable & $\begin{array}{c}\text { Cronbach } \\
\text { Alpha }\end{array}$ \\
\hline Transparency & 0.918 \\
Accountability & 0.913 \\
Responsibility & 0.868 \\
Independence & 0.836 \\
Fairness & 0.907 \\
Sharia Compliance & 0.939 \\
Trust & 0.873 \\
Communication & 0.861 \\
Commitment & 0.902 \\
Customer Intimacy & 0.928 \\
Loyalty & 0.871 \\
\hline Source: Author's calculation &
\end{tabular}

\section{Hypothesis Testing}

Multiple linear regression analysis technique was used to test the hypotheses proposed in this study. Prior to regression testing, the researcher tested the classical assumptions. The results of the classical assumption test show that the research model has met the requirements of the classical assumptions, namely normality (Kolmogorov Smirnov $\mathrm{Z}=$ 0,794; $\mathrm{p}=0,554$ ), multicollinearity (all the variables have Variance Inflation Factor below 10 , ranging from 2,433 to 9,866 ), and heteroscedasticity (there was no particular regular pattern in the scatterplot). The results of the multiple linear regression tests are depicted on Table 2.

Table 2. Regression Results

\begin{tabular}{lcrll}
\hline \multicolumn{1}{c}{$\begin{array}{c}\text { Dependent Variable: } \\
\text { Muzakki Loyalty }\end{array}$} & $\begin{array}{c}\text { Coefficient } \\
(\boldsymbol{\beta})\end{array}$ & $\mathbf{t}$ & $\mathbf{p}$ & \\
\hline Constant & 3,220 & 5,436 & 0,000 & \\
Transparency & 0,177 & 2,715 & 0,007 & $\mathrm{H}_{1}$ supported \\
Accountability & $-0,062$ & $-1,128$ & 0,261 & $\mathrm{H}_{2}$ not supported \\
Responsibility & $-0,005$ & $-0,060$ & 0,952 & $\mathrm{H}_{3}$ not supported \\
Independence & 0,053 & 0,619 & 0,536 & $\mathrm{H}_{4}$ not supported \\
Fairness & 0,125 & 2,205 & 0,029 & $\mathrm{H}_{5}$ supported \\
Sharia Compliance & 0,077 & 2,120 & 0,035 & $\mathrm{H}_{6}$ supported \\
Trust & 0,132 & 1,989 & 0,048 & $\mathrm{H}_{7}$ supported \\
Commitment & $-0,023$ & $-0,301$ & 0,764 & $\mathrm{H}_{8}$ not supported \\
Communication & 0,202 & 2,169 & 0,031 & $\mathrm{H}_{9}$ supported \\
Customer Intimacy & 0,167 & 2,079 & 0,039 & $\mathrm{H}_{10}$ supported \\
F = 56,552; $\mathrm{p}=0,000$ & & & & \\
$\mathrm{R}^{2}=0,750$ Adjusted $\mathrm{R}^{2}=0,736$ & & & & \\
\hline So & & & & \\
\hline
\end{tabular}

Source: Author's calculation 


\section{Effect of Transparency on Muzakki Loyalty}

The first hypothesis (H1) predict that transparency has positive effect on the loyalty of muzakki. Based on the test results, it was found that transparency had a positive significant effect on muzakki loyalty. The results of the regression analysis showed a beta value of transparency of 0.177 with $t$ test value of 2.715 and a significance value less than 0.05 $(0.007<0.05)$. This indicates that the transparency of Amil Zakat Institutions significantly affects muzakki loyalty. Based on the statistical test results, Hypothesis 1 is supported.

The results of this study are in line with the results of Yuliafitri and Khoiriyah (2016) as well as Inayah and Muanisah (2016) work, showing that there is a significant effect of transparency on muzakki loyalty. In the context of zakat management, the transparency principle is defined as disclosure of information related to zakat management.

\section{Effect of Accountability on Muzakki Loyalty}

The second hypothesis (H2) stated that accountability has a positive effect on the loyalty of muzakki. Based on the results of the tests, it was found that accountability did not have any significant effect on muzakki loyalty. The results of the regression analysis showed a beta value of accountability of -0.062 with $t$ test value of -1.128 and a significance value greater than $0.05(0.261>0.05)$. This indicates that the accountability of Amil Zakat Institutions does not have any significant effect on muzakki loyalty. Based on this result, Hypothesis 2 is not supported.

The results of this research supported previous research conducted by Yuliafitri \& Khoiriyah (2016), Purnamasari \& Darma (2015), and Inayah \& Muanisah (2016), which showed that accountability has no effect on loyalty. Most of muzakki only pay attention to the services provided by each Amil Zakat Institution. In addition, muzakki may also lack of knowledge about the meaning of accountability and the institutions may lack of reporting the results of activities in mass media such as magazines, newsletters, and newspapers as well as social media. The respondents in this study did not have any doubt about the accountability of Amil Zakat Institutions in which they pay their zakat. Another reason is the respondents only paid more attention to other things such as programs organized by Amil Zakat Institutions.

\section{Effect of Responsibility on Muzakki Loyalty}

The third hypothesis (H3) predicts that the responsibility has a positive effect on the loyalty of muzakki. Based on the test results, it was found that responsibility did not have significant effect on muzakki loyalty. The result of the regression analysis showed a beta value of responsibility of -0.05 with t test value of -0.060 and a significance value greater than $0.05(0.952>0.05)$. Thus hypothesis 3 is not supported.

This result supported previous research conducted by Purnamasari \& Darma (2015). Supposedly, why responsibility does not have any effect on the loyalty of muzakki in Amil Zakat Institutions is due to the fact that muzakki lack of knowledge about the applicable 
laws and regulations concerning Amil Zakat Institutions and these zakat institutions in Yogyakarta lack of socialization to their muzakki regarding their concern for the community and the environment, causing responsibility to have no effect on muzakki loyalty.

\section{Effect of Independence on Muzakki Loyalty}

Based on the results of the fourth hypothesis (H4) testing, it was found that independence did not have a significant effect on muzakki loyalty. The results of the regression analysis showed a beta value of independence of 0.53 with $t$ test value of 0.619 and a significance value greater than $0.5(0.536>0.05)$. This indicates that the independence of Amil Zakat Institutions does not have any effect on the loyalty of muzakki. For this reason, the fourth hypothesis is not supported.

This research supported previous studies conducted by Purnamasari \& Darma (2015), which showed that independence did not have a significant effect on muzakki loyalty. This is supposedly due to muzakki's higher level of trust in the performance of Amil Zakat Institutions, which already have an authority to regulate and monitor them. Therefore, muzakki registered in Amil Zakat Institutions will assume that each of the business activities carried out by Amil Zakat Institutions adheres to the predetermined standards, thus muzakki do not pay attention to the independence of the Amil Zakat Institution in which they pay their zakat.

\section{Effect of Fairness on Muzakki Loyalty}

The results of the fifth hypothesis (H5) testing proved that there was a significant positive effect of fairness on muzakki loyalty. The calculation using $t$ test resulted in a value of 2.205 with a regression coefficient of 0.125 and a significance level of $0.029(<0.05)$, thus the hypothesis is supported. This test statistically proved that the fairness of Amil Zakat Institutions has a positive significant effect on muzakki loyalty.

The result of this study supported the research conducted by Purnamasari \& Darma (2016) and Ramadan et al., (2018) that found fairness has a positive significant effect on loyalty. This is supposedly because muzakki tend to feel more respected when they are treated fairly without any discrimination.

\section{Effect of Sharia Compliance on Muzakki Loyalty}

The results of the sixth hypothesis (H6) testing proved that there was a significant positive effect of sharia compliance on customer loyalty. Based on regression test, the sharia compliance variable has $t$ value of 2.120 with a regression coefficient of 0.077 and a significance level of $0.035(<0.05)$, thus the hypothesis 6 is accepted. This indicates that sharia compliance held by Amil Zakat Institutions has a positive significant effect on muzakki loyalty. These results are in line with the results of a research by Purnamasari \& Darma (2015) as well as Ramadan et al., (2018), showing that sharia compliance functions 
to increase loyalty. The presence of public awareness of the importance of implementing Islamic principles in performing financial and non-financial transactions also requires Amil Zakat Institutions to apply sharia compliance in each of their operational activities.

\section{Effect of Trust on Loyalty}

The seventh hypothesis (H7) testing showed that there was a significant positive effect of trust on customer loyalty. The variable of trust has $t$ value of 1.989 with a regression coefficient of 0.132 and a significance level of $0.048(<0.05)$, thus the hypothesis 7 is accepted. Based on the results of the hypothesis testing, it can be concluded that trust in Amil Zakat Institutions affects the loyalty of muzakki with a positive direction. The results of this study are consistent with the previous research conducted by Inayah \& Muanisah (2018), Husnain \& Akhta (2015), Tabrani et al., (2018), Ramadan et al., (2018), Wardhani et al. (2017), Razak et al (2018) and Haryeni et al. (2018) which showed that trust increase loyalty. In addition, based on Law number 23 of 2011, the purpose of the establishment of Amil Zakat Institutions is to improve the effectiveness and efficiency of services. In order to achieve such purpose as expected, Amil Zakat Institutions must gain public trust so people are willing to pay their zakat through Amil Zakat Institutions.

\section{Effect of Communication on Loyalty}

Based on the results of the eighth hypothesis (H8) testing in this study, there was a significant positive effect of communication on customer loyalty. The calculation using $t$ test obtained a value of 2.169 with a regression coefficient of 0.202 and a significance level of $0.031 \quad(<0.05)$, thus the hypothesis is supported. This indicates that the communication of Amil Zakat Institutions has a positive effect on muzakki loyalty. The results of this study are supported by the results of some previous studies including Husnain \& Akhtar (2015) and Jesri et al. (2013).

Communication in an organization is highly needed to increase loyalty. This is because communication can support the daily operations of Amil Zakat Institutions, including in collecting and distributing zakat funds, as well as in reporting the collection and distribution of zakat.

\section{Effect of Commitment on Loyalty}

The statistical results of this study indicate that the commitment of Amil Zakat Institutions has no significant effect on muzakki loyalty (H9). This result contradicts with the results of some previous research by Husnain \& Akhtar (2015), Tabrani et al. (2018), Wardhani et al., (2017) and Jesri et al., (2013) that found commitment has a positive and significant effect on loyalty. This is supposedly because muzakki only pay attention to the services of each of Amil Zakat Institutions. In addition, other possible reasons are: muzakki tend to think that the most important thing is to pay zakat to fulfill their obligations and, in terms 
of employees at zakat institutions, the job at Amil Zakat Institutions is only a side job, not a main job.

\section{Effect of Customer Intimacy on Loyalty}

The results of the tenth hypothesis (H10) testing proved that there was a significant positive effect of customer intimacy on customer loyalty. The calculation using t test obtained a value of 2.079 with a regression coefficient of 0.167 and a significance level of $0.039(<0.05)$, thus the hypothesis is accepted. This indicates that customer intimacy in Amil Zakat Institutions (LAZ) has a positive significant effect on muzakki loyalty. The results of this study are consistent with the previous research conducted by Tabrani et al., (2018) and Anggriawan et al., (2015), which showed that customer intimacy increase customer loyalty. However, these results are not in line with a research conducted by Rozi et al., (2014) which shows that customer intimacy does not have any effect on loyalty.

\section{CONCLUSION}

This study found that transparency, fairness, sharia compliance, trust, communication, and customer intimacy have a positive and significant effect on muzakki loyalty. However, the variables of accountability, responsibility, independence and commitment do not have any significant effect on muzakki loyalty. This result indicate that sharia governance and customer relationship marketing partially have a positive and significant effect on muzakki loyalty. In this case customer relationship marketing is more dominant than sharia governance. This research finding informs the Amil Zakat Institution to enhance customer relationship marketing by developing trust-based relationships, improve good communication, and enhance customer intimacy. Besides that, Amil Zakat Institution ought to strengthen sharia governance by increasing transparency, fair treatment to all its stakeholders, and always comply to the sharia principles. The next researcher is suggested to investigate deeper by expanding the scope of the sample not just Lembaga Amil Zakat (LAZ) but also Badan Amil Zakat Nasional (BAZNAS).

\section{REFERENCES}

Anggriawan, F., Widodo, J., \& Kartini, T. (2015). Pengaruh Customer Intimacy Terhadap Loyalitas Nasabah Bank Rakyat Indonesia Syariah Cabang Jember. Artikel Ilmiah Mahasiswa, 1(1), 1-7.

Ardiansyah, D. O. (2016). Pengaruh Komunikasi Terhadap Kinerja Karyawan dengan Dimediasi oleh Kepuasan Kerja (Studi pada Bagian Produksi Pabrik Kertas PT. Setia Kawan Makmur Sejahtera Tulungagung). Jurnal Bisnis dan Manajemen, 3(1), 16-30. Asrori. (2011). Pengungkapan Syari'ah Compliance dan Kepatuhan Bank Syariah Terhadap Prinsip Syariah. Jurnal Dinamika Akuntansi, 3(1), 1-7.

Fadilah, S. (2012). Penerapan Good Fovernance Pada Lembaga Amil Zakat. Bandung. Unpad Press. 
Firdaus, M., Beik, I. S., Irawan, T., \& Juanda, B. (2012). Economic Estimation and Determinations of Zakat Potential in Indonesia. IRTI Working Paper Series, WP\# 1433-07.

Haryeni, Mulyati, Y., \& Laoli, R. F. (2018). Kualitas Pelayanan, Kepercayaan, Kepuasan Nasabah dan Pengaruhnya Terhadap Loyalitas Nasabah pada Tabungan Bank Rakyat Indonesia (PERSERO) TBK Kantor Cabang Khatib Sulaiman. Jurnal Ekonomi \& Bisnis Dharma Andalas, 18(1), 19-39.

Husnain, M., \& Akhtar, M. W. (2015). Relationship Marketing and Customer Loyalty: Evidence from Banking Sector in Pakistan. Global Journal of Management and Business Research: E Marketing, 15(10), 1-15.

Inayah, N., \& Muanisah, Z. (2018). Hubungan Kepercayaan, Transparansi dan Akuntabilitas Terhadap Loyalitas Muzakki Pada Badan Amil Zakat. ACTIVA: Jurnal Ekonomi Syariah, 1(2), 18-33.

Indrawaty \& Wardayati, S. M. (2016). Implementing Islamic Corporate Governance (ICC) and Islamic Social Reporting (ISR) in Islamic Financial Institution (IFI). Procedia Social and Behavioral Sciences 219, 338-343.

Jesri, P., Ahmadi, F., \& Fatchipoor, M. (2013) Effects of Relationship Marketing (RM) on Customer Loyalty (Case Study: Mehr Bank, Kermashah Province Iran). Interdisplinary Journal of Contemporary Research Business, 4(11), 304-312.

Junusi, R. El. (2016). Implementasi Syariah Governance Serta Implikasinya Terhadap Reputasi dan Kepercayaan Bank Syariah. Annual International Conference on Islamic Studies (AICIS XIII), 6(1), 1828-1848.

KNKG. (2006). Pedoman Umum Good Corporate Governance. Jakarta. Komite Nasional Kebijakan Governance.

Kotler, P., \& Armstrong, G. (2018). Principles of Marketing. $17^{\text {th }}$ Ed. London: Pearson.

Mubarok, A., \& Fanani, B. (2014). Penghimpunan Dana Zakat Nasional (Potensi, Realisasi dan Peran Penting Organisasi Pengelola Zakat). PERMANA, V(2), 7-16.

Ndubisi, N. O. (2015). Relationship Marketing and Customer Loyalty. Marketing Inteligence \& Planning, 7(1), 98-106.

Purnamasari, I., \& Darma, E. S. (2015). Pengaruh Implementasi Syariah Governance Terhadap Loyalitas Nasabah. Jurnal Akuntansi dan Investasi, 16(1), 12-24.

Pusat Kajian Strategis Badan Amil Zakat Nasional (BAZNAS). (2017). Outlook Baznas Indonesia: Jakarta Pusat.

Rahman, A. (2018). Potensi Zakat Indonesia Rp 200 Triliun Tapi. https://finansial.bisnis.com/read/20180125/86/730096/potensi-zakat-indonesia-rp200triliun-tapi.

Ramadan, R., Askandar, N. S., \& Amin, M. (2018). Pengaruh Implementasi Syariah Governance Terhadap Loyalitas Nasabah. E-JRA, 07(01), 32-45.

Razak, A., Baberi, J., \& Ramadhan, M. I. (2018). Pengaruh Kepuasan dan Kepercayaan Terhadap Loyalitas Nasabah pada Bank Negara Indonesia (BNI) Cabang Kendari. Sigma: Journal of Economic and Business, 1(79), 10-20.

Rijal, K., \& Nilawati. (2019). Potensi Pembayaran Zakat Secara Online dan Offline Serta Realisasi Dana Zakat Indonesia. I-Economics: A Research Journal on Islamic Economics, 5(2), 116-131. 
Rozi, A. F., Sularso, R. A., \& Dimyati, M. (2014). Dampak Elemen Customer Relationship Marketing Terhadap Loyalitas Pelanggan Rumah Makan Bebek 88. Unej Jurnal 1(1), $1-6$.

Tabrani, M., Amin, M., \& Nizam, A. (2018). Trust, Commitment, Customer Trust, Commitment, Customer Intimacy and Customer Loyalty in Islamic Banking Relationship. International Journal of Bank Marketing, 36(5), 823-848.

Tjiptono, F. (2012). Strategi Pemasaran. Edisi Kedua. Yogyakarta: Andi Offset.

Yuliafitri, I. \& Khoiriyah, A. N. (2016). Pengaruh Kepuasan Muzakki, Transparansi Dan Auntabilitas Pada Lembaga Amil Zakat Terhadap Loyalitas Muzakki. Islamiconimic: Jurnal Ekonomi Islam, 7(2), 205-218.

Wardhani, W. K., Fauzi, A., \& Arifin, Z. (2017). Pengaruh Relationship Marketing (Pemasaran Hubungan) Terhadap Loyalitas. Jurnal Administrasi Bisnis (JAB), 51(1), 39-43.

Warsono, S., Amalia, F., \& Rahajeng, D. K. (2009). Corporate Governance Concept and Model. Yogyakarta: Center of Good Corporate Governance.

Wantara, P. (2015). The Relationships Among Service Quality, Customer Satisfaction, and Customer Loyalty in Library Services. International Journal of Economics and Financial Issues, 5(1), 264-269. 